\title{
Auto-immunity to prostate antigen in rheumatic disease
}

\author{
A. GRIMBLE
}

From Guy's Hospital, London

SYNOPSIS Sera from cases of rheumatic disorder were tested against antigen extracted from humanw prostate by the haemagglutination method. The reactions were compared with those obtaineक⿱乛क using antigens from liver, kidney, and colon. It was found that most cases of Reiter's syndrome; ankylosing spondylitis, and some of uveitis possess circulating antibodies to prostate tissue. The significance of this result in cases of Reiter's syndrome is discussed and compared with the resultsi

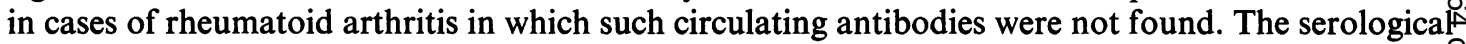
pattern in these disorders is compared with that found in acute rheumatic fever, where a more severe immune disturbance is to be expected. An exact explanation for the role of auto-immunization $\vec{z}$ must await further experimental evidence.

\section{MATERIAL AND METHODS}

The antigens were prepared by the phenol extraction method. Each was prepared in the same way, and the method for prostate is described in detail.

Fresh, healthy human tissue from a person younger than middle age and dying by accident was dissected, cut fine, and placed in a retort with about $100 \mathrm{ml}$. of distilled water and $100 \mathrm{ml}$. pure phenol, heated for half an hour at $65^{\circ} \mathrm{C}$., and stirred. After cooling and centrifugation the watery layer was pipetted off and was retained. The phenolic phase was once again mixed with $100 \mathrm{ml}$. distilled water and heated as before. After centrifugation the watery layer was again pipetted off and mixed with the first. This watery extract was now dialyzed against distilled water, lyophilized, and then resuspended in about $100 \mathrm{ml}$. of distilled water. The solution was mixed with an equal quantity of ethanol and stirred. The precipitate was filtered off, and the remaining solution mixed with 6 to 10 volumes of ethanol. The precipitate obtained was suspended in about $10 \mathrm{ml}$. of distilled water and lyophilized. The final powder was dissolved in $5 \mathrm{ml}$. distilled water and diluted for use (Broberger and Perlmann, 1959). The final powder was that obtained from two prostate glands. These glands naturally varied both in size and parenchymal substance, and, as absolute accuracy was not possible at this point, care was taken to obtain a working solution comparable with that of other specimens. The final powder usually amounted to almost $5 \mathrm{mg}$.

The serological method used was tanned red cell haemagglutination, in which the red cell surface is modified to adsorb proteins. Sheep red cells were washed three times and made up in a $4 \%$ suspension. An equal volume of freshly made up tannic acid $(1: 20,000)$ was added to the suspension and it was left at room temperaReceived for publication 6 October 1963. ture for 10 minutes before centrifugation and removal of the supernatant. The cells were washed with normab saline and resuspended at $2 \%$. The antigen was prepareee at a suitable strength for the test, and $5 \mathrm{ml}$. was mixed with $5 \mathrm{ml}$. of the $2 \%$ suspension of the red cells and the mixture left at room temperature for half an houro mixing occasionally. This suspension was again centrifuged and the supernatant discarded. The red cells were then washed and resuspended in $5 \mathrm{ml}$. of guinea-pig serum ready for use. Each serum was first adsorbed with uncoated sheep red cells.

The antigen at first was used at an arbitrary dilution (using an opacity meter) until the test had run for a triars period. When a suitable strength had been found byo opacity, this dilution was used to make further seriaB dilutions of antigen which were trial-tested againsto known positive sera. In this way a more exact measure of? the optimum antigen dilution was obtained for the test. In the final series of tests the patients' sera were set up in serial dilutions of $1: 5,1: 25,1: 125,1: 625,1: 3,125$, and a control tube without serum was also set up. Ten drops of을 normal saline were placed in all tubes and one drop of red cells. The tubes were left at room temperature foro one hour and at $4^{\circ} \mathrm{C}$. overnight before being read. $N$ Agglutination at $1: 125$ or above was considered fully positive, whereas agglutination at 1:25 was considered $\omega$ weakly positive. The result at $1: 5$ was discarded.

\section{RESULTS}

INITIAL SERIES An initial series of tests was under-0 taken using the antigens at an empirical potency. In $\vec{P}$ this first series, when 38 sera from cases of Reiter's syndrome were tested using prostatic antigen $37 \mathrm{D}$ gave positive results. When five of these sera weres tested against antigen of liver, kidney, and colon 
one gave a positive response with liver, one a doubtful positive response with kidney, and all showed negative response with colon.

Of five sera from cases of rheumatoid arthritis three gave positive reactions in low titre against prostate $(<1: 10)$ and two each with liver and kidney antigen. In four cases of acute rheumatic fever the results were positive in sera from three cases with each of the three antigens-prostate, liver, and kidney. Sera from nine cases of uveitis were tested, eight being positive with prostate antigen (seven in low titre) and it was doubtful if there were any positive result with either liver or kidney. Of sera from five cases of ankylosing spondylitis all gave positive reactions with prostatic antigen in low titres, as against one positive result with kidney and one doubtful positive with liver antigen.

Sera from 10 healthy women were used as controls in this series; all were negative. Also 70 miscellaneous sera from out-patients were tested: positive reactions to prostate antigen occurred in six.

FINAL SERIES OF TESTS These were undertaken with an optimal strength of antigen as described, using a different set of serum dilutions as stated above. The results are set out in Table I. In 21 sera from

\begin{tabular}{|c|c|c|c|c|}
\hline \multirow{3}{*}{ Disorder } & \multicolumn{4}{|c|}{ TABLE I } \\
\hline & \multirow{2}{*}{$\begin{array}{l}\text { No. of } \\
\text { Cases }\end{array}$} & \multicolumn{3}{|c|}{ Antigen (nos. positive) } \\
\hline & & Prostate & Liver & Kidney \\
\hline Reiter's syndrome & 21 & 20 & 4 & 4 \\
\hline Rheumatoid arthritis & 18 & 2 & 1 & 0 \\
\hline Rheumatic fever & 7 & $\overline{7}$ & 5 & 4 \\
\hline Uveitis & 9 & 4 & 0 & 0 \\
\hline Ankylosing spondylosis & 8 & 8 & 2 & 2 \\
\hline
\end{tabular}

cases of Reiter's syndrome there were 16 strongly positive, four weakly positive, and one negative reaction, using prostate antigen. Using liver antigen, there were two strongly positive and two weakly, and using kidney antigen there were four weakly positive results (Table II).

In 18 sera from cases of rheumatoid arthritis there was one agglutination using liver, none using kidney antigen, and one weak and one strong positive using prostate antigen. In seven cases of acute rheumatic fever all gave positive reactions against prostate, five gave positive reactions against liver, and four against kidney.

Of eight sera from cases of ankylosing spondylitis all gave positive reactions to prostate, and two each to liver and kidney. Of nine sera from cases of uveitis four gave positive reactions to prostate and none to liver or kidney.

Finally sera from nine cases of subacute prostatitis were tested. All except one gave positive
TABLE II

Titres of Agglutinations to Antigens of

Prostate Liver Kidney

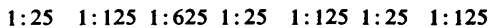

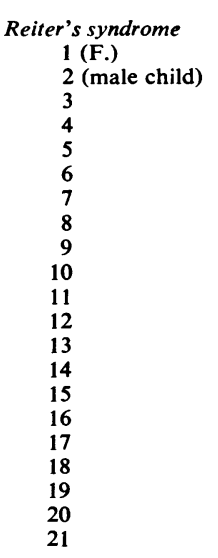

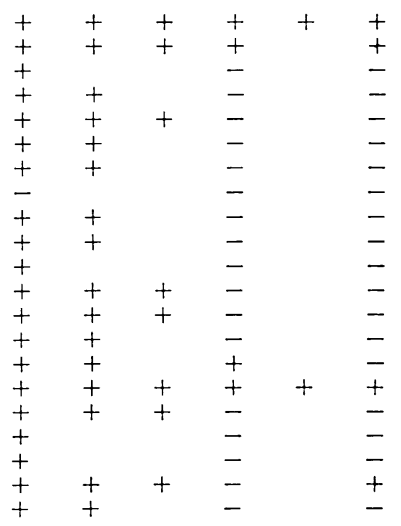

$\begin{array}{cr}\text { Ankylosing spondylosis } \\ 1 & + \\ 2 & + \\ 3 & + \\ 4 & + \\ 5 & + \\ 6 & + \\ 7 & +\end{array}$

$\begin{array}{rrrr}\text { Uveitis } & & & \\ 1 & + & - & - \\ 2 & - & - & - \\ 3 & + & - & - \\ 4 & - & - & - \\ 5 & - & - & - \\ 6 & - & - & - \\ 7 & - & - & - \\ 8 & + & - & -\end{array}$

Rheumatoid arthritis

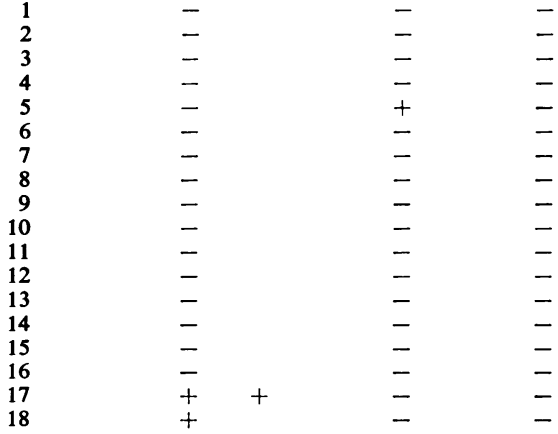

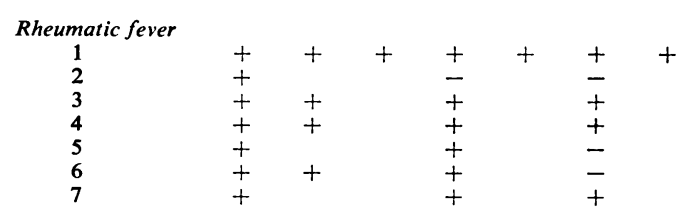


reactions to prostate and none against liver or kidney.

\section{DISCUSSION}

The aetiology of Reiter's syndrome is unknown. In the majority of cases it follows non-specific urethritis and its complications, especially prostatitis, which precedes the attack of arthritis in virtually every case in the adult male. Despite close search the pathogenic microorganisms have not so far been established as a cause of the disease. The pseudovirus myocplasma and $T$. vaginalis have not been proved to have an aetiological role, although the latter certainly may cause urethritis and prostatitis. The fact that the virus $C$. oculogenitale has been cultured recently raised hopes that it might be responsible for Reiter's syndrome but there is yet no evidence to support this claim. Since pathogenic bacteria are almost never found in the urethral or prostatic secretion in this condition, there is the obvious possibility that there may be some other than a specific infective cause for Reiter's syndrome.

The results of the haemagglutination reactions reported here seem to suggest that there are circulating auto-antibodies in this disorder, and also that the serum reaction to prostatic antigen is not only stronger in Reiter's syndrome than in several other disorders but it is more constantly reactive with this antigen than with those produced from three other tissues.

There are several possible interpretations of such an antigen-antibody reaction: it could represent (1) a non-specific reaction which is known to occur in a group of disorders, such as the "collagen disorders', and in particular disseminated lupus erythematosus where there is altered antibody production; (2) a reaction with an antigen which is not organ-specific, but which contains vascular and supportive tissue extracts; (3) a specific reaction between antigen and antibody, the former derived from a particular organ parenchyma.

In the patients with Reiter's syndrome, ankylosing spondylitis, and possibly uveitis, there was a difference between the responses with prostatic antigen and those prepared from other tissues. In rheumatic fever this difference was not significant, which suggests that here a non-specific alteration in the antibody response was responsible. On the other hand, our results suggest that the reactions with sera from patients with Reiter's syndrome were mainly of the third type. It can be seen (Tables I and II) that the results in Reiter's syndrome and in ankylosing spondylitis are in sharp contradistinction to the results obtained on the one hand in rheumatic fever and on the other in rheumatoid arthritis. It is also interesting in view of the erroneously held opinion that colitis is a necessary part of this syndrome (Lancet, 1962) that sera from Reiter? syndrome did not react with colon antigen.

The interpretation of the presence of auto? antibodies in Reiter's syndrome should be made wit caution. It is uncertain to what extent auto-antibod is produced in the body and what is its precise significance despite present research and speculatiom (Lancet, 1961; Annals of Internal Medicine, 1960 Homologous tissue is said not to be antigenic in normal circumstances. The presence of auto: antibody therefore seems to indicate a failure of normal function, although it is not possible t 8 . conclude what that failure is nor whether it has direct bearing on the pathogenesis of the disease. $\vec{v}$

It is tempting to infer that the presence of subacute prostatitis results in the production of auto-antio bodies (Table III). Whereas these antibodies have been shown to occur infrequently, if at all, in males of various age groups in whom the diagnosis has not been entertained (Table III), they occurred in the्ष

\begin{tabular}{|c|c|c|}
\hline Clinical Group & $\begin{array}{l}\text { No. of } \\
\text { Cases }\end{array}$ & $\begin{array}{l}\text { Nos. } \\
\text { Positive }\end{array}$ \\
\hline $\begin{array}{l}\text { Prostatitis } \\
\text { Miscellaneous male, age-grouped second }\end{array}$ & 9 & 8 \\
\hline to eighth decade & 25 & 0 \\
\hline Miscellaneous females & 20 & $\mathbf{0}$ \\
\hline Healthy females & 10 & 0 \\
\hline Total miscellaneous out-patients & 70 & $6^{1}$ \\
\hline
\end{tabular}

${ }^{1}$ These patients were cases of myxoedema (f. aged 46), thyroiditis (f. aged 50), rheumatoid arthritis (m. aged 59), asthma (m. aged 39 ? ulcerative colitis (m. aged 51 ), Reiter's syndrome (m) subsequently included in the study.

majority of cases of subacute prostatitis. This forni of prostatitis is often not readily diagnosed unles? looked for, the presenting symptoms frequently being slight and vague. The fact that subacute prostatitis is known to underlie Reiter's syndrome? ankylosing spondylitis, and uveitis in the male is significant (Mason, Murray, Oates, and Young? 1958; Romanus, 1953; Catterall, 1958). It is also interesting that the exact aetiology of this form of prostatitis, apart from the fact that it frequentlo follows urethritis, remains in doubt, despite a good deal of investigation (Gartman 1958; Ghormley Cook, and Needham, 1953; Proceedings of thw Royal Society of Medicine, 1955).

Auto-antibodies to various human tissue antigens have been found fairly extensively in recent years

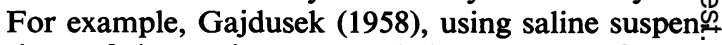
sions of tissue, demonstrated the presence of auto=0 antibodies by the complement fixation technique Prostatic tissue amongst others was used but came in for little comment. However, suspensions of tissue from five cases of rheumatic fever were tested against liver antigen; four were negative and one् 
positive, and three of them tested against kidney were negative. Similarly sera from six cases of rheumatoid arthritis were all negative when tested against liver antigen but three were positive against kidney.

One would not expect sera from women to react with prostatic antigen except as an epiphenomenon. Sera from 10 healthy young women gave no positive reaction, nor was there any reaction from sera from 20 female out-patients. Agglutinations did take place, however, in sera from two female out-patients tested later, one a case of myxoedema and the other a case of Hashimoto's thyroiditis in which a high titre of anti-thyroid antibodies was present. Similarly, agglutinations did not take place in sera from seven female patients with rheumatoid arthritis, although conversely, in the male group, positive results were obtained in two of the 11 sera.

It seems likely from the evidence presented that antibody to prostate tissue may be produced in subacute prostatitis and in disorders related to it. Whether there is a quantitative or qualitative difference when such conditions as Reiter's syndrome supervene has not been answered. The question whether these immune bodies are playing a primary or a secondary role in the pathogenesis of Reiter's syndrome must await further experimental evidence.

Further immunological tests with analysis of serum components might throw some light on this but it seems likely that the application of the postulates of Witebsky, Rose, Terplan, Paine, and Egan (1957), which state in effect that the disease must be experimentally reproducible, making use of the aetiological agents considered to be responsible for the human disease, in this way working by analogy from animals, will provide the most useful line of approach. This method has already been used with success in thyroiditis and neuritis (Rose and Witebsky, 1956; Waksman and Adams, 1955). The presence of this immunological disturbance would have additional significance if a definite role in the pathogenesis of Reiter's syndrome could be assigned to it.

Gajdusek (1958) was able to conclude from his evidence that the complement-fixing antibodies which he demonstrated were in all probability classical antibodies associated with the gamma globulin fraction. They therefore represented the effect of a specific stimulus on the body's immune mechanisms, and were not the result of an adventitious reaction. The specificity of this reaction is important, since reactions in low titre with a sensitive test are not infrequent, and the very wide occurrence of so-called non-syphilitic antibodies to myocardial tissue must be remembered. It seems therefore that there exists another group of disorders which are associated in some way with the immune processes of the body and associated specifically with them as they apply or are related to prostatic inflammation. If, as is sometimes thought, a disorder of this nature represents a chink in the body's homeostatic armour, which normally protects it against the ill-effects of such auto-immunity, then a profitable subject for enquiry exists here. Autoimmunity, in this instance related to a rheumatic disorder, precedes the onset of rheumatic illness, since it is apparent that only a proportion of cases of prostatitis are followed by Reiter's syndrome or other minimal signs of this disease. Since this complication does not inevitably follow one must infer that there are other factors along with immunological ones which are responsible for an attack of Reiter's syndrome. It is hoped to gather further evidence towards a solution of this problem first by demonstrating complement-fixing antibodies and performing antigen absorption studies, and subsequently by further work with the prostate gland and experimental immune studies as suggested above. Preliminary results have in fact shown the presence of complement-fixing antibodies and that the phenomenon of immune absorption can be satisfactorily demonstrated with these sera from cases of Reiter's syndrome but not from cases of rheumatic fever.

\begin{tabular}{|c|c|c|c|}
\hline HAEMAGGLUTINATION & $\begin{array}{l}\text { TEST RESULTS } \\
\text { ANTIGEN }\end{array}$ & WITH & PROSTATIC \\
\hline $\begin{array}{l}\text { Titres before Absorption } \\
\text { with Prostatic Antigen }\end{array}$ & After Absorption & & \\
\hline
\end{tabular}

\section{Reiter's syndrome}

Positive 1:625

Positive 1:625

Positive 1:125

Positive 1: 125

$\begin{array}{ll}- & \begin{array}{l}\text { Control case of } \\ \text { unabsorbed serum } \\ \text { positive }\end{array}\end{array}$

Rheumatic fever

Positive 1:125

Positive 1:125

Positive $1: 125$

Positive $1: 125$

My thanks are due to the many colleagues who so kindly sent me sera from their patients, and to Mr. Theophanides for his invaluable technical help.

\section{REFERENCES}

Ann. intern. Med., (1960). 52, 930.

Broberger, O., and Perlmann, P. (1959). J. exp. Med., 110, 657.

Catterall, R. D. (1958). Trans. ophthal. Soc. U.K., 78, 523.

Gajdusek, D. C. (1958). Arch. intern. Med., 101, 9.

Gartman, E. (1958). Brit. J. vener. Dis., 34, 181.

Ghormley, K. O., Cook, E. N., and Needham, G. M. (1953). J. Amer. med. Ass., 153, 915.

Lancet (1961). 2, 245.

(1962). 1, 1111.

Mason, R. M., Murray, R. S., Oates, J. K., and Young, A. C. (1958) Brit. med. J., 1, 748.

Proc. roy. Soc. Med., (1955). 48, 413.

Romanus, R. (1953). Acta med. scand., 145, suppl. 280.

Rose, N. R., and Witebsky, E. (1956). J. Immunol., 76, 417.

Waksman, B. H., and Adams, R. D. (1955). J. exp. Med., 012, 213.

Witebsky, E., Rose, N. R., Terplan, K., Paine, J. R., and Egan, R. W (1957). J. Amer. med. Ass., 164, 1439. 